\title{
Influence of Cross-Listing on the Relationship between Financial Leverage and R\&D Investment: A Sustainable Development Strategy
}

\author{
Chi-Lin Yang ${ }^{1}\left(\mathbb{D}\right.$ and Jung-Ho Lai ${ }^{2, *}$ \\ 1 Department of Urban Industrial Management and Marketing, University of Taipei, Taipei 11153, Taiwan; \\ clyang@utaipei.edu.tw \\ 2 Department of Finance, National Taipei University of Business, Taipei 10051, Taiwan \\ * Correspondence: julialai@ntub.edu.tw
}

check for

updates

Citation: Yang, C.-L.; Lai, J.-H. Influence of Cross-Listing on the Relationship between Financial Leverage and R\&D Investment: A Sustainable Development Strategy. Sustainability 2021, 13, 10341.

https://doi.org/10.3390/su131810341

Academic Editors:

Manuel Au-Yong-Oliveira and Maria José Sousa

Received: 6 August 2021

Accepted: 14 September 2021

Published: 16 September 2021

Publisher's Note: MDPI stays neutral with regard to jurisdictional claims in published maps and institutional affiliations.

Copyright: (C) 2021 by the authors. Licensee MDPI, Basel, Switzerland. This article is an open access article distributed under the terms and conditions of the Creative Commons Attribution (CC BY) license (https:// creativecommons.org/licenses/by/ $4.0 /)$.

\begin{abstract}
Investment in research and development (R\&D) is an important sustainable strategy for firms in developing unique products to own their differentiation and competitive advantages. Financial leverage is influential in R\&D investment. However, previous studies identified different relationship between financial leverage and R\&D investment. This study revisits this puzzle from a unique perspective that targets firms undertaking international cross-listings. This specification allows us to test whether firms are willing to prioritize R\&D funding when debt capacity is enhanced. This is a new perspective that has never been explored in the relationship between debt financing and R\&D investment. We find that the launch of cross-listing significantly increases the level of firm financial leverage, which is followed by a significant increase in corporate investment in $R \& D$. The aggressive strategy of cross-listing firms that enhance financial leverage to support more investment in $R \& D$ further significantly influences their industrial rivals to increase investment in $R \& D$ as a responding strategy. Overall, these results show that firms exploit the timing of international cross-listing to increase their leverage to further fund $R \& D$, which also stimulates an intra-industry contagion effect. Our findings suggest a new viable path for funding R\&D that carries important implications for corporate sustainability.
\end{abstract}

Keywords: cross-listing; financial leverage; R\&D investment; corporate sustainability

\section{Introduction}

The prior literature indicates that firms with sufficient funds to invest in research and development (R\&D) can create sustainable development advantages and accumulate in-tangible assets [1-4]. This study aims to investigate the relationship between financial leverage and R\&D investment. Financial leverage is conceptualized as the debt-to-assets ratio which describes the source of firm financing from debt relative to equity. Opler and Titman [5] consider that it is important for firms to take debt financing on R\&D investment. R\&D capacity is critical to the long-term sustainability of firms, as it develops firms' abilities to enhance their product uniqueness and novelty, which increases customer loyalty and their switching cost to rival firms. Thus, customers tend to be highly concerned about the firm's long-term sustainability as they are highly dependent on continuous support from the firm [6]. Conversely, if a firm's product is substitutable, it is easy for customers to switch to other suppliers without incurring high switching costs. This suggests that firms should attempt to conduct significant R\&D investments to increase their product uniqueness and differentiation from rival firms, as this can increase customers' switching costs and sustain a firm's development advantage.

A great amount of investment in R\&D facilitates the development of greater product uniqueness and increases a firm's competitiveness, but on the other hand, R\&D activities are characterized by a high failure rate, particularly those having a high degree of 
uniqueness [7]. This leads to a contradiction for the relationship between the level of financial leverage and R\&D investment. In other words, firms, for the purpose of long-term organizational sustainability, particularly those in highly competitive product markets, should extensively utilize their debt capacity to fund R\&D activities to enhance product uniqueness and thus firm competitiveness. By contrast, the high failure rate of R\&D may make debt holders, who are not compensated for higher risk taking, hesitate to provide sufficient funding. Thus, the relationship between financial leverage and R\&D investment has been found to be controversial in the literature. For the object of long-term organizational sustainability, firms should extensively utilize their debt capacity to fund R\&D activities to enhance the uniqueness and innovation of products [8-10], particularly in high-tech environments or highly competitive product markets. Thus, the impact of financial leverage on R\&D investment has been found to be controversial in the academic literature.

In the present study, we revisit this important issue by utilizing a unique dataset that explores the influence of cross-listing on the relationship between financial leverage ratio and firm R\&D investment. We argue that one important explanation for the extant mixed findings of the relationship between $R \& D$ expenditure and leverage ratio is that prior studies do not incorporate the influence of the firm's debt capacity, that is, a firm's ability to increase debts [8-10]. We overcome this problem by targeting firms that conduct cross-listing on major U.S. stock markets to explore this relationship. According to the related literature, the introduction of cross-listing can increase a firm's debt capacity via two paths. First, the issue of American depository receipts (ADRs) implies that firms gain a significant amount of external capital from equity markets, which reduces bankruptcy risk and provides extensive financial slack for managers to raise debt financing [8-11]. Next, by cross-listing, firms must comply with more stringent disclosure requirements and are subjected to stronger laws protecting investors $[12,13]$. Thus, a successful cross-listing signals the market about firms' improved capital structure. Particularly, considering that U.S. stock exchanges are among the largest capital markets worldwide characterized by sophisticated investors and strict regulations of going public [12,13], it can convince the focal firm's domestic investors and bankers that the firms have improved their financial soundness, thereby facilitating their debt financing.

By observing 215 sample firms outside the U.S. that announced their first ADR programs on major U.S. exchanges during the 2010-2019 period, our study shows that crosslisting firms launch their ADR issues to increase their leverage ratios (i.e., use of debt financing) to higher proportions than before undertaking these ADR issues. The significant increase in financial leverage is accompanied by a significant increase in firms' $R \& D$ investments, which subsequently further arouse the intra-industry contagion effect that prompts their opponents to compete with R\&D expenditures as responses.

While the extant findings on the relationship between financial leverage ratio and firm R\&D investment remain controversial, consequences of this study can contribute to the research stream from a unique perspective, that is, by observing a sample of international businesses that undertook cross-listing on major U.S. stock exchanges. This unique specification allows us to test if a firm is willing to raise leverage to fund R\&D investments when possessing the financing ability, and whether the conduct of cross-listing stimulates a rival firm's aggressive R\&D financing motive. This view has never been examined in the literature. Our findings should inspire corporations to be eager for a new strategy in R\&D investments to develop their sustainability.

The remainder of the study is structured as follows: First, we review the theoretical background and build the hypotheses in Section 2. Next, Section 3 presents the sample selection, variable definitions, and statistics. We then discuss the empirical results in Section 4 and provide the implications in Section 5. Finally, Section 6 gives the conclusions.

\section{Theoretical Background}

Previous studies indicate that a firm's sustainable competitiveness mainly derives from unique and inimitable intangible assets, such as intellectual property or patent rights, 
which are mostly developed through substantial R\&D investments [14]. However, R\&D investments are characterized by high risk and a great amount of sunk cost, which hamper its external financing [15]. A review of the literature shows an ambiguous influence of firm financial leverage on R\&D investments. First, the perspective of agency cost $[16,17]$ argues a negative impact of financial leverage on R\&D investments. The agency theory considers that the result of R\&D investments leads to conflicts of interests between debt holders and shareholders. This is because, although taking the risk of R\&D projects allows shareholders to gain higher risk premiums, debt holders cannot similarly share in the risk premium reward that flows from successful R\&D projects as do shareholders but only gain a fixed amount of interest. However, both debt holders and shareholders suffer bankruptcy costs from unsuccessful R\&D projects. The unbalanced risk-reward relationship thus makes debt holders unwilling to fund significant $R \& D$ expenditures.

Second, the information asymmetry problem further causes debt holders to reduce investments in R\&D projects when managers keep information confidential for competitive reasons. Under such circumstances, debt holders have trouble with forecasting the consequences of $R \& D$ projects. Considering the unbalanced risk-reward relationship characterizing debt financing, the concern of informational asymmetry increases the difficulty that managers use debt financing for R\&D projects than for other less risky capital projects $[3,18,19]$.

Finally, from the perspective of transaction costs, the financing decision of firms counts principally on the attributes of asset properties. In particular, the level of intangibility and uniqueness of business have a negative impact on using debt financing [20]. According to transaction cost theory, intangible assets are difficult to write explicit contracts to protect and thus their transactions suffer from the great hazard of opportunism [21,22]. Meanwhile, unique firm assets are not suggested as collaterals for loans because their values are costly if deployed for other uses and could be carelessly distributed by outsiders [23]. Since R\&D investments tend to create intangible and unique firm assets, R\&D investments should have less debt financing to avoid their value being appropriated by other firms $[20,23]$.

Against this view, there is an alternative perspective suggesting a positive relationship between financial leverage and R\&D investment. For example, the disciplinary role of debt can have a positive impact on managerial behavior, leading to managerial investment in projects with positive net present value [24]. This is because corporate debt requires firm managers to generate cash to meet interest and principal obligations; thus, managers willingness to undergo monitoring by external financing markets signals their prudent use of firm capital [25]. R\&D projects undertaken under a high debt ratio thus are expected to create firm value because of the effective outside monitoring. Consistent with this viewpoint, a previous study finds that $R \& D$ expenditures of firms with a high debt ratio create significantly positive abnormal returns [26].

We revisit the conundrum by analyzing cross-listing events on major U.S. stock exchanges, a new perspective never used to study the impact of financial leverage (i.e., debt ratio) on R\&D investment. The previous studies indicate that firms implement cross-listing introductions to obtain an international reputation and greater financial resources $[4,27,28]$. These cross-listing activities positively advance both firm growth and corporate value. This is especially true considering that U.S. stock exchanges have been recognized as the most representative in the world, where many foreign businesses from different countries eager to cross-list attempt to do so [12,13]. A successful ADR cross-listing can significantly enhance a firm's reputation and convince the external capital market that the firms have improved their debt capacity. Further, due to the strict regulations of the United States Securities and Exchange Commission (SEC), a successful cross-listing can signify that firms have advanced their competitiveness and financial soundness. The reputational advantage of successful cross-listing facilitates an increase in leverage ratio higher than before undertaking the cross-listing. Due to the importance of R\&D investments for firms' sustainability and long-term prosperity, we consider that cross-listing firms take advantage 
of the increased debt capacity to fund more R\&D investments relative to other activities. These arguments result in the succeeding hypotheses.

Hypothesis 1 (H1). Foreign firms launch the ADR cross-listing (as successful issue of ADR in the U.S. stock exchanges significantly increases a firm's reputation) to increase the use of debt financing to an even higher proportion (i.e., raise their leverage ratio higher by utilizing the reputation effect brought by the successful issue of ADR) compared with the time before cross-listing in the U.S. stock exchanges.

Hypothesis 2 (H2). When cross-listing firms increase the leverage ratio, they use a greater amount of debt to conduct more RED investments.

Finally, due to the increasingly competitive globalized environment, we argue that the aggressive strategy of cross-listing firms that greatly increase their debt financing to fund more R\&D investments also prompts their industrial rivals to adopt similar strategies as responses. As the perspective of product market competition states, for a firm that has highly differentiated products, customers become highly reliant on continuous support from this firm, which enhances the switching cost of customers and consequently the competitive strength of firms [6]. The literature shows that firms who adopt aggressive $R \& D$ investment strategies typically survive in an industrial environment characterized by a highly competitive industry structure [15]. Under such a competitive environment, for one firm that successfully cross-lists to fund more R\&D signals than opponents, then its R\&D capacity is enhanced due to better access to international resources. We think that industrial rivals similarly increase their R\&D investment to avoid being outraced by focal firms that increase financial leverage to fund more $R \& D$ investment. Thus, we have the argument as follows:

Hypothesis 3 (H3): The aggressive RED financing strategy (a significant increase in RED investments using greater financial leverage) of cross-listing firms arouses a contagion effect pushing industrial rivals to also enhance their RED investments in response.

\section{Research Methodology}

\subsection{Sample Selection}

These sample firms consisted of stocks traded outside the U.S. that announced their first ADR programs to list on the U.S. stock exchanges including AMEX, NASDAQ, and NYSE. These sample firms were obtained from the Bank of New York. Following the related literature on financial leverage, we did not include financial firms with SIC codes from 6000 to 6999 and utilities with SIC code from 4900 to 4999 into the sample. To avoid other impacts that contaminate our findings, we excluded firms that trade Level I ADR (OTC), privately placed ADR, and offshore ADR (SEC Rule 144A/Regulations) [29]. Further, we eliminated cross-listing firms if their financial information was unavailable from the Center for Research in Securities Prices (CRSP) database and the Compustat database.

We then used this process to adopt the firms increasing the amount of their debt financing that is, those who raised significant debts compared to their existing firm assets before undertaking cross-listing. This procedure helped to ensure that our sample firms could raise abundant debts via cross-listing and had these financial resources to expand $R \& D$ expenditures. The measurement of debt financing was calculated as:

$$
\text { Debt Financing }=\left(\text { Long-term Debt }_{0}-\text { Long-termDebt }_{-1}\right) / \text { Asset }_{-1}
$$

Following the definition of debt financing as in [10], we measured debt financing as the difference between long-term debts in the cross-listing year and long-term debts in the prior year and then divided by lagged firm assets (the unit of percentage).

Because this study concentrated on the competition in the market, the samples were further restricted to obey these criteria: (i) the minimum of debt financing in year 0 (the year 
of the ADR event undertaking) was $2 \%$ of the amount of firm assets in year -1 (the year prior to the ADR event launching); (ii) the minimum in an industry was two firms; (iii) the minimum in the market share was $1 \%$; (iv) we could acquire their R\&D expenditures in the Compustat database from year -1 to year 0 (named as year $[-1,0]$ ); and (v) firms were not involved in any mergers and acquisitions in year 0 .

Finally, we collected the sample of rival firms in the U.S. stock markets including AMEX, NASDAQ, and NYSE from 2010 to 2019. The rival firms belonged to U.S. corporations and their four-digit SIC codes were the same as the four-digit SIC codes of the cross-listing firms [30-32]. We adopted these firms to be the sample firms and rival firms. The samples of 215 firm events raising the amount of debt financing in the period 2010-2019 were identified. Because of these constraints, the minimum in every event window was two years. Thus, the competitive impact in this study could be attributed to the chosen event during the following two years.

\subsection{Descriptions of Variables}

\subsubsection{Dependent Variable}

Obtaining the data of R\&D investments from the Compustat database, we then estimated the difference in R\&D in year 0. In Equation (2), on the basis of $[2,7,14,15,19]$, we defined this variable, and it was equal to the $R \& D$ expenditure in year 0 minus the $R \& D$ expenditure in year -1 and then divided by firm assets in year -1 . Thus, the measurement of the dependent variable was expressed as follows:

$$
\Delta R \& D_{0}=\left(R \& D_{0}-R \& D_{-1}\right) / \text { Asset }_{-1}
$$

Moreover, we calculated the industrial modified difference in R\&D expenditure. We computed these R\&D investments of sample firms and those of industrial rival firms. The industrial modified difference in R\&D expenditure was equal to the change in R\&D of a sample firm in year 0 minus the mean of the changes in R\&D of the others with the same four-digit SIC code in year 0 .

\subsubsection{Independent Variable}

While the issue of ADR increased a firm's equity share, we questioned whether crosslisting firms would utilize the reputation brought about by the successful ADR issue to increase their financial leverage ratio (i.e., the amount of debt financing) to an even higher proportion than before undertaking the ADR issue. In Equation (3), according to [8-11,33], we calculated the difference of leverage as follows:

$\Delta$ Leverage $_{0}=\left[\left(\right.\right.$ Long-term Debt $_{0}+$ Short-term Debt $\left._{0}\right)-\left(\right.$ Long-term Debt $_{-1}+$ Short-term Debt_1 $\left.\left._{-1}\right)\right] /\left(\right.$ Asset $\left._{-1}\right)$

Following [8-11,33], we measured the difference of leverage by the change between the sum of long-term and short-term debts in year 0 and the sum of long-term and shortterm debts in year -1 . We used this variable, $\Delta$ Leverage $_{0}$, as the measurement of increase in leverage ratio in this study.

\subsection{Descriptive Statistics}

Table 1 presents the distribution of our sample firms according to the year when they launch the ADR cross-listing, as well as the amount of debt financing as defined by Equation (1). First, we find a slowly growing trend in the cross-listings. Further, we discover that the amount of debt financing increases stably measured by either mean or median of debt financing. The mean of debt financing in all samples is $15.31 \%$, and its median is $15.69 \%$. As the mean was almost equal to the median, the result shows that the distribution of sample is nearly symmetrical (i.e., without outliers). Finally, the significant positive mean and median values of debt financing across the event years suggest that most sample firms use significant debt financing along with the launch of cross-listings. 
Table 1. Sample distribution and debt financing by year.

\begin{tabular}{cccc}
\hline \multirow{2}{*}{ Year } & Observations & \multicolumn{2}{c}{ Debt Financing (\%) } \\
\cline { 3 - 4 } & & Mean & Median \\
\hline 2010 & 21 & 12.62 & 12.98 \\
2011 & 23 & 13.36 & 13.87 \\
2012 & 18 & 14.47 & 14.82 \\
2013 & 24 & 15.23 & 15.56 \\
2014 & 28 & 15.32 & 15.64 \\
2015 & 25 & 15.62 & 15.78 \\
2016 & 30 & 15.88 & 16.12 \\
2017 & 21 & 16.15 & 16.34 \\
2018 & 16 & 16.32 & 16.56 \\
2019 & 43 & 16.57 & 17.38 \\
Total & 215 & 15.31 & 15.69 \\
\hline
\end{tabular}

\section{Empirical Results}

\subsection{Univariate Analysis}

We conducted a univariate analysis to examine Hypothesis 1 . First, we computed the debt financing by Equation (1) to choose those firms whose minimum of debt financing in year 0 was $2 \%$ of the amount of firm assets in year -1 . Next, for those achieving the minimum of debt financing threshold, we then calculated their difference in leverage by Equation (3). The results are summarized in Table 2.

Panel A shows the results of all sample firms. We find that the difference in leverage ( $\Delta$ Leverage) is positive with the mean value of $3.30 \%$ and median value of $3.15 \%$. The result is consistent with Hypothesis 1, suggesting that firms would introduce the ADR cross-listing to increase the leverage ratio to a higher level than before cross-listing. Panel $B$ shows the results of the subsample of leverage-increasing firms (those with positive value of $\Delta$ Leverage). We find that in year -1 , the leverage (Debt/Asset -1 ) of cross-listing sample firms is slightly lower than that of their industrial rivals; the mean (median) of leverage for sample firms is $19.12 \%(18.87 \%)$, and their rivals' mean (median) is $19.35 \%$ $(19.56 \%)$. However, in year 0, the mean (median) of leverage (Debt / Asset 0 ) for the leverageincreasing subsample is $22.54 \%(23.16 \%)$, both being higher than their rivals' mean $(17.86 \%)$ and median $(17.95 \%)$. Furthermore, their mean and median of $\Delta$ Leverage is $7.23 \%$ and $7.18 \%$, respectively, both being much higher than those of all samples.

Panel $C$ reports the results of the subsample of leverage-decreasing firms (those with negative value of $\Delta$ Leverage). In year -1 , their mean of leverage (Debt/Asset -1 ) is $21.04 \%$, and median is $17.32 \%$, both being higher than their rivals' mean $(10.21 \%)$ and median $(10.52 \%)$. By contrast, in year 0, their mean (median) of leverage (Debt/Asset $\left.t_{0}\right)$ is $10.33 \%$ $(8.95 \%)$, both being slightly lower than their rivals' mean $(11.32 \%)$ and median $(11.05 \%)$. Furthermore, for the leverage-decreasing subsample, their mean and median of $\Delta$ Leverage are $-4.18 \%$ and $-4.52 \%$, respectively, both being lower than those of all sample.

Table 2 also compares the number of leverage-increasing firms (141) versus the number of leverage-decreasing firms (74). The result of greater number of leverage-increasing firms in contrast to leverage-decreasing firms suggests that a majority of firms take advantage of the ADR issuing to increase their leverage ratio to above that of their rivals. Overall, these univariate test results support Hypothesis 1.

We provide the differences in R\&D expenditures in Table 3. There are three panels: all firms in Panel A, leverage-increasing firms in Panel B, and leverage-decreasing firms in Panel $C$, respectively. We measured the unmodified change through the difference in R\&D expenditures in year $[-1,0]$ divided by firm assets in year -1 . The industrial modified difference was equal to the unmodified difference in the sample firm minus the mean of the unmodified difference in the rest of firms in an industry. For Hypothesis 2, we report the results of conducting a univariate analysis in Table 3. These values of all sample analyses are found in Panel A. The unmodified values of R\&D expenditures and industrial 
modified values are reported. We find that the mean of the unmodified differences in R\&D expenditure increased by $1.88 \%(p<0.05)$ in year $[-1,0]$, increased by $2.54 \%(p<0.05)$ in year $[-1,1]$ and increased by $3.85 \%(p<0.05)$ in year $[-1,2]$, respectively. These results indicate that firms continued to input $R \& D$ expenditures for at least 2 years after raising debt financing.

Table 2. Statistics descriptions.

\begin{tabular}{|c|c|c|c|c|}
\hline & Mean (\%) & Median (\%) & S.D. (\%) & Observation \\
\hline & \multicolumn{4}{|c|}{ A. All sample } \\
\hline Debt financing & 15.31 & 15.69 & 6.62 & 215 \\
\hline$\Delta$ Leverage & 3.30 & 3.15 & 3.44 & 215 \\
\hline Debt/Asset_-1 & 19.78 & 18.34 & 14.16 & 215 \\
\hline Debt/Asset 0 & 18.34 & 18.27 & 13.91 & 215 \\
\hline Debt/Asset -1 of rival firms & 16.20 & 16.45 & 12.76 & 215 \\
\hline Debt / Asset 0 of rival firms & 15.61 & 15.58 & 11.77 & 215 \\
\hline Number of firms in the industry & 14.34 & 13.00 & 12.84 & 215 \\
\hline Herfindahl index & 1211 & 8.23 & 2.14 & 215 \\
\hline \multirow[t]{2}{*}{ Market share of all firms } & 7.30 & 6.53 & 12.22 & 215 \\
\hline & \multicolumn{4}{|c|}{ B. Leverage-increasing firms } \\
\hline Debt financing & 10.19 & 10.21 & 4.83 & 141 \\
\hline$\Delta$ Leverage & 7.23 & 7.18 & 3.58 & 141 \\
\hline Debt/Asset_-1 & 19.12 & 18.87 & 13.51 & 141 \\
\hline Debt/Asset 0 & 22.54 & 23.16 & 15.38 & 141 \\
\hline Debt/_ Asset -1 of rival firms & 19.35 & 19.56 & 14.45 & 141 \\
\hline Debt / Asset 0 of rival firms & 17.86 & 17.95 & 13.24 & 141 \\
\hline Number of firms in the industry & 14.00 & 13.00 & 12.47 & 141 \\
\hline Herfindahl index & 13.57 & 8.83 & 2.29 & 141 \\
\hline \multirow[t]{2}{*}{ Market share of leverage-increasing firms } & 8.23 & 7.41 & 13.22 & 141 \\
\hline & \multicolumn{4}{|c|}{ C. Leverage-decreasing firms } \\
\hline Debt financing & 25.07 & 26.13 & 10.02 & 74 \\
\hline$\Delta$ Leverage & -4.18 & -4.52 & 3.18 & 74 \\
\hline Debt/Asset_-1 & 21.04 & 17.32 & 15.41 & 74 \\
\hline Debt / Asset 0 & 10.33 & 8.95 & 11.12 & 74 \\
\hline Debt/Asset -1 of rival firms & 10.21 & 10.52 & 9.54 & 74 \\
\hline Debt / Asset 0 of rival firms & 11.32 & 11.05 & 8.98 & 74 \\
\hline Number of firms in the industry & 15.00 & 13.00 & 13.54 & 74 \\
\hline Herfindahl index & 9.33 & 7.08 & 1.85 & 74 \\
\hline Market share of leverage-decreasing firms & 5.53 & 4.86 & 10.32 & 74 \\
\hline
\end{tabular}

The mean of industrial modified differences in R\&D expenditures is positively significant with the value of $0.83 \%(p<0.05)$ in year $[-1,0]$. The mean of industrial modified differences in R\&D expenditures in year $[-1,1]$ is $0.98 \%(p<0.05)$ and in year $[-1,2]$ is $1.37 \%(p<0.05)$, respectively. Overall, we find that the cross-listing firms' $R \& D$ expenditure increases industrial rivals in the cross-listing year and the two subsequent years.

In Panel B, we illustrate the results of leverage-increasing firms. The unmodified difference in R\&D expenditures of leverage-increasing samples increased significantly by $2.05 \%(p<0.05)$ in year $[-1,0]$. In year $[-1,1]$ and year $[-1,2]$, the means of unmodified differences in R\&D expenditures are significant at $2.68 \%(p<0.05)$ and $3.83 \%(p<0.05)$, respectively. Further, the mean of industrial modified differences in R\&D expenditures in year $[-1,0]$ is $0.88 \%(p<0.05)$. This shows that the leverage-increasing firms increased their R\&D expenditures higher than those of their industrial rivals. The mean of industrial modified differences in $R \& D$ expenditures in year $[-1,1]$ is also significantly positive at $1.15 \%(p<0.05)$ and maintains the significantly positive value of $1.36 \%(p<0.05)$ in year $[-1,2]$. These results indicate that during the cross-listing period, the leverage-increasing 
firms were more aggressive in raising R\&D expenditures than their industrial rivals, which is consistent with Hypothesis 2.

Table 3. Differences in R\&D expenditures.

\begin{tabular}{|c|c|c|c|c|}
\hline \multirow{2}{*}{\multicolumn{2}{|c|}{ Initial Amount (\%) of $R \& D_{-1} / A s s e t_{-1}$}} & \multicolumn{3}{|c|}{ Differences in R\&D Expenditures (\%) } \\
\hline & & $\begin{array}{c}2 \text { Year Period: } \\
\text { Year }[-1,0]\end{array}$ & $\begin{array}{c}3 \text { Year Period: } \\
\text { Year }[-1,1]\end{array}$ & $\begin{array}{l}4 \text { Year Period: } \\
\text { Year }[-1,2]\end{array}$ \\
\hline \multicolumn{2}{|c|}{ Panel A. All firms $(\mathrm{N}=215)$} & \multicolumn{3}{|c|}{ Unmodified values } \\
\hline Mean & $3.26 *$ & $1.88 *$ & $2.54 *$ & $3.85 *$ \\
\hline \multirow[t]{2}{*}{ Median } & $3.78 *$ & $1.54 *$ & $2.65 *$ & $3.96^{*}$ \\
\hline & & \multicolumn{3}{|c|}{ Industrial modified values } \\
\hline Mean & $1.15^{*}$ & $0.83 *$ & $0.98 *$ & $1.37 *$ \\
\hline Median & 0.12 & $0.25+$ & 0.36 * & 0.58 * \\
\hline \multicolumn{2}{|c|}{ Panel B. Leverage-increasing firms $(\mathrm{N}=141)$} & \multicolumn{3}{|c|}{ Unmodified values } \\
\hline Mean & $3.42 *$ & $2.05 *$ & $2.68 *$ & $3.83 *$ \\
\hline \multirow[t]{2}{*}{ Median } & $3.95 *$ & $2.12 *$ & $2.82 *$ & $4.12 *$ \\
\hline & & \multicolumn{3}{|c|}{ Industrial modified values } \\
\hline Mean & $1.26 *$ & $0.88 *$ & $1.15^{*}$ & 1.36 * \\
\hline Median & $0.45 *$ & $0.38 *$ & $0.47 *$ & $0.61 *$ \\
\hline \multicolumn{2}{|c|}{ Panel C. Leverage-decreasing firms $(\mathrm{N}=74)$} & \multicolumn{3}{|c|}{ Unmodified values } \\
\hline Mean & $1.25+$ & 0.83 & $1.11+$ & $1.28+$ \\
\hline \multirow[t]{2}{*}{ Median } & $1.16+$ & 0.82 & $1.12+$ & $1.25+$ \\
\hline & & \multicolumn{3}{|c|}{ Industrial modified values } \\
\hline Mean & 0.53 & 0.47 & 0.52 & 0.62 \\
\hline Median & 0.30 & 0.17 & 0.25 & 0.38 \\
\hline
\end{tabular}

For comparison, we also analyzed the subsample of leverage-decreasing firms. The results are reported in Panel C. Compared to the leverage-increasing firms, these leveragedecreasing firms have a positive mean of unmodified differences in R\&D investments in year $[-1,0]$, which is insignificant at $0.83 \%$. Similarly, the means of industrial modified differences in R\&D expenditures of these leverage-decreasing firms in year $[-1,0](0.47 \%)$, year $[-1,1](0.52 \%)$ and year $[-1,2](0.62 \%)$ are all positive but insignificant.

\subsection{Regression Analysis}

The prior literature $[34,35]$ indicated that it was necessary to control variables that may influence $R \& D$ expenditure, including the growth in firm assets, the amount of $R \& D$ expenditures in year -1 , market share, and several industrial structure variables. It was noteworthy that since $R \& D$ investments were found to be a continuous event that may last for 2-3 years after launch, we used three time-window years $[-1,0]$, year $[-1,1]$, and year $[-1,2]$, respectively, for more robust results [36]. We considered the linear regression model from these studies $[2,7,14,15,19]$ as follows:

$$
\begin{aligned}
\Delta R \& D_{i t} & =\beta_{0 t}+\beta_{1 t} \text { Ddebt }_{i}+\beta_{2 t} \log (\text { H index })_{i}+\beta_{3 t} \text { Number of firms in the industry } \\
& +\beta_{4 t} \text { Market share of sample firm }{ }_{i}+\beta_{5 t} \text { Industrial modified amount of } R \& D_{-1 i} \\
& +\beta_{6 t} \text { Industrial modified growth ratio of firm assets from year }-1 \text { to year } t_{i}+\varepsilon_{i t},
\end{aligned}
$$

The difference in $R \& D$ expenditures of all firms was the dependent variable. The industrial modified R\&D expenditures from year -1 to year $\mathrm{t}$ for firm $i$, where $t$ was equal to 0,1 , and 2 depending on different time windows (i.e., time-window year $[-1,0]$, year $[-1,1]$, and year $[-1,2])$. Ddebt took a value equal to 1 in the case of the increases in leverage, and zero otherwise. We named the logarithm of the Herfindahl index as log 
( $\mathrm{H}$ index). The number of firms in the industry was the total number of firms in the industry. We adopted the industrial modified amount of $R \& D$ expenditures in year -1 to control the changes of R\&D expenditures in these ADR events. We also used the industrial modified growth ratio of firm assets to control the changes in the growth ratio of firm assets in these ADR events. We also measured the standard errors of these coefficients due to heteroscedasticity [37].

The empirical results of the regression analysis are found in Table 4. First, about the effect of control variables, the coefficients of the industrial modified values of R\&D expenditures in year -1 are significantly positive throughout all models $(0.26,0.34$, and 0.48 , respectively). This means that the effect of industrial modified values of R\&D expenditures in year -1 on the $R \& D$ growth rate is a significantly positive effect $(p<0.01)$. The coefficients of the industrial modified growth ratio of firm assets are all significantly positive in all models $(0.12,0.14$, and 0.15$)$. This means that the effect of the industrial modified growth ratio of firm assets on the $R \& D$ growth ratio is also a significantly positive effect $(p<0.01)$. Further, the coefficients about number of firms are significantly positive in year $[-1,1](0.03, p<0.05)$ and year $[-1,2](0.04, p<0.05)$, respectively. However, the coefficient of $\log (\mathrm{H}$ index) is not significant to support the difference in $\mathrm{R} \& \mathrm{D}$ expenditures. The coefficient of market share is also insignificant to support the difference in R\&D expenditures. After controlling for possible impacts of the control variables as suggested in the prior literature, the coefficients of debt are significantly positive in three regressions $(0.02$, $p<0.05 ; 0.03, p<0.01$; and $0.05, p<0.01$, respectively). We find these consistent results in Table 3 , thereby further supporting Hypotheses 1 and 2. This suggests that firms increased their financing leverage to be aggressive in R\&D investments in terms of undertaking more R\&D investments relative to their industrial rivals. Overall, in Table 4, the results of regression analyses present that the firms whose financial leverages increased during the cross-listing period conduct more vigorous $R \& D$ investment strategies after controlling for other variables.

Table 4. Regression analysis: differences in R\&D expenditures.

\begin{tabular}{|c|c|c|c|}
\hline & $\begin{array}{l}2 \text { Year Period: } \\
\text { Year }[-1,0]\end{array}$ & $\begin{array}{l}3 \text { Year Period: } \\
\text { Year }[-1,1]\end{array}$ & $\begin{array}{l}4 \text { Year Period: } \\
\text { Year }[-1,2]\end{array}$ \\
\hline Ddebt & $\begin{array}{l}0.02 \text { * } \\
(2.24)\end{array}$ & $\begin{array}{l}0.03 * * \\
(2.45)\end{array}$ & $\begin{array}{l}0.05^{* *} \\
(2.44)\end{array}$ \\
\hline $\log (\mathrm{H}$ index $)$ & $\begin{array}{c}0.02 \\
(0.56)\end{array}$ & $\begin{array}{c}0.02 \\
(0.61)\end{array}$ & $\begin{array}{c}0.02 \\
(0.63)\end{array}$ \\
\hline Number of firms in the industry & $\begin{array}{c}0.03 \\
(0.32)\end{array}$ & $\begin{array}{l}0.03 * \\
(1.73)\end{array}$ & $\begin{array}{l}0.04 * \\
(1.78)\end{array}$ \\
\hline Market share of sample firms & $\begin{array}{c}0.02 \\
(0.71)\end{array}$ & $\begin{array}{c}0.02 \\
(0.66)\end{array}$ & $\begin{array}{c}0.04 \\
(0.55)\end{array}$ \\
\hline Industrial modified amount of $R \& D_{-1}$ & $\begin{array}{l}0.26^{* *} \\
(2.54)\end{array}$ & $\begin{array}{l}0.34^{* *} \\
(2.61)\end{array}$ & $\begin{array}{l}0.48^{* *} \\
(2.69)\end{array}$ \\
\hline Industrial modified growth ratio of firm assets & $\begin{array}{l}0.12 \text { ** } \\
(2.65)\end{array}$ & $\begin{array}{l}0.14^{* *} \\
(2.72)\end{array}$ & $\begin{array}{l}0.15^{* *} \\
(2.79)\end{array}$ \\
\hline Intercept & $\begin{array}{c}-1.11 \\
(-1.32)\end{array}$ & $\begin{array}{c}-1.54 \\
(-1.24)\end{array}$ & $\begin{array}{c}-1.59 \\
(-1.32)\end{array}$ \\
\hline Adjusted $R^{2}(\%)$ & 12.75 & 12.81 & 12.84 \\
\hline Number & 215 & 215 & 215 \\
\hline
\end{tabular}

T-statistics are in parentheses. ${ }^{* *}$ and ${ }^{*}$ are significant at 1 and $5 \%$, respectively.

To test if the aggressive R\&D investment conducted by cross-listing firms using greater financial leverage push their industrial rivals to also enhance their R\&D investment in response as suggested by Hypothesis 3, we conducted a further regression analysis to examine rival firms' reactions to these firms' expanding R\&D investments. In this regard, we focused on the results of the 141 subsample of leverage-increasing firms and showed that $R \& D$ expenditures significantly increased post cross-listing. However, the 74 leverage- 
decreasing subsample firms show the insignificant change in R\&D investments around cross-listing.

To investigate the effect of competition, the firms in each rival group were separated into two categories: (1) the differences in $R \& D$ expenditures of firms from year -1 to year $t$ were over the average in the industry; (2) these differences $R \& D$ expenditures of firms from year -1 to year $t$ were under the industrial average. The former category was characterized by relatively aggressive firms, and the latter category comprises relatively passive firms. We examined the financing effect of these firms' financial leverage on their industrial peers and whether this effect makes these rivals aggressive or passive in R\&D investments. Specifically, the logistic regression was estimated from these studies $[2,7,14,15,19,38]$ as follows:

$$
\begin{aligned}
\text { Aggressive }_{i t} & =\beta_{0 t}+\beta_{1 t} \text { Industrial modified leverage } \\
& +\beta_{3 t} \text { Industrial modified amount of } R \& \beta_{2 t} \text { Market share }_{i} \\
& +\beta_{4 t} \text { Industrial modified growth ratio of firm assets from year }-1 \text { to year } t_{i}+\varepsilon_{i t},
\end{aligned}
$$

The dependent variable took a value equal to 1 in the case of the differences in $R \& D$ investments of rival firms being greater than the average of industrial differences in $R \& D$ investments, and zero otherwise. We measured the industrial modified leverage through the unmodified amount minus the average of the unmodified amount in the industry. The other variables had the same definitions in the above equations. The four-digit SIC codes of rival firms and those of the sample firms were the same. To explain the rivals' reactions to these sample firms, we excluded the financing-events if two or more rival firms raised their debt financing in the same year.

We present the probability of rival firms taking aggressive R\&D investments in Table 5. The result of logistic regression indicates that the industrial modified leverage of the sample firms is significantly and positively related to the level of rival firms' aggressiveness in these three periods, year $[-1,0]$, year $[-1,1]$, and year $[-1,2]$, thereby supporting Hypothesis 3 . The impacts of both initial levels of R\&D expenditure and the growth ratios of firm assets are also significantly negative throughout all models $(p<0.01)$. The effects of market share, by contrast, are insignificant in the three models. Overall, the results in Table 5 demonstrate a significant intra-industry contagion effect suggesting that the aggressive R\&D financing strategies of cross-listing firms (i.e., a significant increase in $R \& D$ investments by using greater financial leverage) push their industrial rivals to also enhance R\&D investment

\begin{tabular}{|c|c|c|c|}
\hline & $\begin{array}{c}2 \text { Year Period: } \\
\text { Year }[-1,0]\end{array}$ & $\begin{array}{c}3 \text { Year Period: } \\
\text { Year }[-1,1]\end{array}$ & $\begin{array}{l}4 \text { Year Period: } \\
\text { Year }[-1,2]\end{array}$ \\
\hline Industrial modified leverage & $\begin{array}{l}0.52 * \\
(1.97)\end{array}$ & $\begin{array}{l}0.64^{* *} \\
(2.35)\end{array}$ & $\begin{array}{l}0.67 * \\
(2.43)\end{array}$ \\
\hline Market share & $\begin{array}{c}0.23 \\
(0.41)\end{array}$ & $\begin{array}{c}0.26 \\
(0.44)\end{array}$ & $\begin{array}{l}0.35 \text { * } \\
(1.97)\end{array}$ \\
\hline Industrial modified amount of $R \& D_{-1}$ & $\begin{array}{l}-1.62 \text { ** } \\
(-2.42)\end{array}$ & $\begin{array}{l}-1.67^{* *} \\
(-2.51)\end{array}$ & $\begin{array}{l}-1.68^{* *} \\
(-2.53)\end{array}$ \\
\hline Industrial modified growth ratio of firm assets & $\begin{array}{l}-0.89 * * * \\
(-2.38)\end{array}$ & $\begin{array}{l}-0.84^{*} \\
(-2.27)\end{array}$ & $\begin{array}{l}-0.82 * * \\
(-2.24)\end{array}$ \\
\hline Intercept & $\begin{array}{l}-0.49 * * \\
(-1.97)\end{array}$ & $\begin{array}{l}-0.51 \text { ** } \\
(-1.98)\end{array}$ & $\begin{array}{l}-0.54^{* *} \\
(-2.12)\end{array}$ \\
\hline Number & 141 & 141 & 141 \\
\hline
\end{tabular}
in response.

Table 5. Logistic regressions of rival firms taking aggressive R\&D investments.

T-statistics are in parentheses. ${ }^{* * *},{ }^{* *}$, and ${ }^{*}$ are significant at 1,5 , and $10 \%$, respectively.

\subsection{Robustness Testing}

We adopted an instrumental variable approach to examine the robustness of our findings. It provided the evidence to support the hypotheses that changes in financial 
leverage lead to changes in R\&D competition not contaminated by endogeneity bias [39]. To implement this process, we first identified these related instrument variables to test the propensity of raising financing. In this aspect, the decision of firms' debt financing was obviously influenced by the financial leverage of industrial peers in the same industry [40]. Thus, it was a good proxy for firms to adopt the average of industrial leverage as the difference in leverage. Second, this study constructed a competitive strategy measure (CSM) to run the model on the basis of [41]. It was defined as the response of the change in marginal profits relative to output, compared with a change in competitor outputs. This concept measured the effect of differences in quantity on marginal profit in the industry. We used the model of instrumental variables in accordance with these studies $[2,7,14,15,19,38,41]$ to measure the relationship between R\&D and leverage as follows:

$$
\begin{aligned}
R \& D_{i t} & =\beta_{0 t}+\beta_{1 t} \text { Predicted probability of increasing leverage }_{i} \\
& +\beta_{2 t} \log (\text { H index })_{i}+\beta_{3 t} \text { Number of firms in the industry }_{i} \\
& +\beta_{4 t} \text { Market share of sample firm }{ }_{i}+\beta_{5 t} \text { Industrial modified amount of } R \& D_{-1 i} \\
& +\beta_{6 t} \text { Industrial modified growth ratio of firm assets from year }-1 \text { to year } t_{i}+\varepsilon_{i t},
\end{aligned}
$$

We defined industrial modified difference in $R \& D$ investments as the dependent variable. The industrial modified difference was equal to the unmodified change of the sample firm minus the average in the unmodified change of the others in the industry. The unmodified difference was equal to the change in R\&D expenditures from year $[-1,0]$ divided by firm assets in year -1 . In particular, the predicted probability of increasing leverage was from the logistic regression according to [41] as follows:

$$
\text { Ddebt }_{i t}=\beta_{0 t}+\beta_{1 t} \text { Average in leverage }_{i}+\beta_{2 t} \mathrm{CSM}_{i}+\varepsilon_{i t},
$$

Ddebt took a value equal to 1 in case of increases in leverage, and zero otherwise. We named the average industrial leverage as average in leverage. CSM was the proxy of strategic market competition. These standard errors of the coefficient were estimated in this procedure due to heteroscedasticity [37].

The parameter estimates of Equation (7) are as follows: The coefficient of average in leverage is significantly positive, and it is related to the probability of raising leverage $(p<0.01)$. The coefficient of CSM is also significantly negative $(p<0.01)$. This is consistent with the concept of strategic market competition.

We present the results of instrumental variable analysis in Table 6 . The coefficients about the predicted probability of increasing leverage are significantly positive in these

\begin{tabular}{|c|c|c|c|}
\hline & $\begin{array}{l}2 \text { Year Period: } \\
\text { Year }[-1,0]\end{array}$ & $\begin{array}{c}3 \text { Year Period: } \\
\text { Year }[-1,1]\end{array}$ & $\begin{array}{l}4 \text { Year Period: } \\
\text { Year }[-1,2]\end{array}$ \\
\hline Predicted probability of increasing leverage & $\begin{array}{l}0.13^{* *} \\
(2.50)\end{array}$ & $\begin{array}{l}0.15^{* *} \\
(2.51)\end{array}$ & $\begin{array}{l}0.16^{* *} \\
(2.65)\end{array}$ \\
\hline $\log (\mathrm{H}$ index $)$ & $\begin{array}{c}0.02 \\
(0.27)\end{array}$ & $\begin{array}{c}0.02 \\
(0.28)\end{array}$ & $\begin{array}{c}0.02 \\
(0.28)\end{array}$ \\
\hline Number of firms in the industry & $\begin{array}{c}0.02 \\
(0.13)\end{array}$ & $\begin{array}{l}0.03 \text { * } \\
(2.03)\end{array}$ & $\begin{array}{l}0.03 \text { * } \\
(1.77)\end{array}$ \\
\hline
\end{tabular}
three models. The results provide strong evidence to support the contention that the manager likely raises the level of debt financing to be consistent with the increase invested in R\&D.

Table 6. Instrumental variable analysis. 
Table 6. Cont.

\begin{tabular}{|c|c|c|c|}
\hline & $\begin{array}{l}2 \text { Year Period: } \\
\text { Year }[-1,0]\end{array}$ & $\begin{array}{c}3 \text { Year Period: } \\
\text { Year }[-1,1]\end{array}$ & $\begin{array}{l}4 \text { Year Period } \\
\text { Year }[-1,2]\end{array}$ \\
\hline Market share & $\begin{array}{c}0.02 \\
(0.34)\end{array}$ & $\begin{array}{c}0.02 \\
(0.39)\end{array}$ & $\begin{array}{c}0.01 \\
(0.39)\end{array}$ \\
\hline Industrial modified amount of $R \& D_{-1}$ & $\begin{array}{l}0.36^{* *} \\
(2.51)\end{array}$ & $\begin{array}{l}0.42^{* *} \\
(2.58)\end{array}$ & $\begin{array}{l}0.49^{* *} \\
(2.61)\end{array}$ \\
\hline Industrial modified growth ratio of firm assets & $\begin{array}{l}0.22 \text { ** } \\
(2.41)\end{array}$ & $\begin{array}{l}0.33^{* *} \\
(2.52)\end{array}$ & $\begin{array}{l}0.37^{* *} \\
(2.66)\end{array}$ \\
\hline Intercept & $\begin{array}{c}-0.88 \\
(-0.33)\end{array}$ & $\begin{array}{l}-0.82 \\
(-0.33)\end{array}$ & $\begin{array}{c}-0.81 \\
(-0.34)\end{array}$ \\
\hline Adjusted $R^{2}(\%)$ & 13.12 & 13.17 & 13.20 \\
\hline Number & 215 & 215 & 215 \\
\hline
\end{tabular}

T-statistics are in parentheses. ${ }^{* *}$ and ${ }^{*}$ are significant at 1 and $5 \%$, respectively.

\section{Implications}

This study makes several contributions to the academic literature and has managerial implications. First, this article investigates the impact of financial leverage on R\&D investments from a new perspective. The previous literature explored the effect of financial leverage on $R \& D$ expenditure from the perspectives of transaction cost $[7,14,23]$, agency theory $[18,26]$, information asymmetry [19], and so forth. We adopted a theoretical view of the competitive behavior in the product market to re-examine the puzzle. This is the first time that this unique perspective has been considered in the academic literature.

Second, the prior literature mostly concentrated on the "static" relationship between the level of financial leverage and the level of R\&D expenditure [20,42]. We provided the "dynamic" change value of these two variables. Our results show that firms successfully launch cross-listing to enhance debt financing for R\&D funding compared with the period before cross-listing. This finding inspires the firms to be eager for R\&D investment in a new viable path.

Finally, we analyzed this issue by using a unique sample: international businesses cross-listing in the U.S. stock market. Previous studies thought that firms make crosslistings to obtain more financial resources $[4,27,28]$. This research finds that cross-listing activities can positively improve the growth and value of firms. Particularly, it considers that under the strict regulation of the SEC, a successful cross-listing can significantly raise a firm's reputation and provide a way to approach the stock market in the U.S. [12,13]. Thus, it can improve shareholder protection and liquidity so that firms can develop their debt capacity. This means firms can increase debt financing and leverage to increase R\&D investments.

\section{Conclusions}

An important strategy for corporate sustainability is R\&D investments. This study is concerned with the event of cross-listing, and this affects the decisions of both financial leverage and R\&D investments. This article chooses a competitive perspective to address this issue. It provides empirical evidence that the cross-listing event has significant impacts on financial leverage and $R \& D$ expenditure.

There are some findings in this study. First, we find that the foreign firms who undertook cross-listings in the U.S. stock exchanges on average significantly increased their debt financing. Second, we find that cross-listing firms take advantage of the reputation brought about by successful ADR issue to increase their financial leverage ratio to an even higher proportion than before the ADR issue. Finally, we find that the aggressive R\&D financing strategy of cross-listing firms arouses a contagion effect to make industrial rival firms raise their R\&D investments in response significantly. 
Author Contributions: All the authors contributed to the conceptualization, formal analysis, investigation, methodology, writing of the original draft, and writing review and editing. All authors have read and agreed to the published version of the manuscript.

Funding: This study was supported by the Ministry of Science and Technology of Taiwan, R.O.C. under grant MOST 110-2410-H-141-011-.

Institutional Review Board Statement: Not applicable.

Informed Consent Statement: Not applicable.

Data Availability Statement: Data available on request due to restrictions, e.g., privacy or ethical.

Acknowledgments: The authors are grateful to the editor and anonymous reviewers at Sustainability for their valuable comments and suggestions that have significantly improved the quality of this study.

Conflicts of Interest: The authors declare no conflict of interest.

\section{References}

1. Gleason, K.; Mathur, L.; Mathur, I. The Interrelationship between Culture, Capital Structure, and Performance: Evidence from European Retailers. J. Bus. Res. 2000, 50, 185-191. [CrossRef]

2. Lee, N.; Lee, J. External Financing, R\&D Intensity, and Firm Value in Biotechnology Companies. Sustainability $2019,11,4141$. [CrossRef]

3. Marchica, M.; Mura, R. Financial Flexibility, Investment Ability, and Firm Value: Evidence from Firms with Spare Debt Capacity. Financ. Manag. 2010, 39, 1339-1365. [CrossRef]

4. Schoubben, F.; Hulle, C. Stock Listing and Financial Flexibility. J. Bus. Res. 2011, 64, 483-489. [CrossRef]

5. Opler, T.; Titman, S. Financial Distress and Corporate Performance. J. Financ. 1994, 49, 1015-1040. [CrossRef]

6. Arping, S.; Loranth, G. Corporate Leverage and Product Differentiation Strategy. J. Bus. 2006, 79, 3175-3207. [CrossRef]

7. Parida, V.; Wincent, J.; Oghazi, P. Transaction Costs Theory and Coordinated Safeguards Investment in R\&D Offshoring. J. Bus. Res. 2016, 69, 1823-1828.

8. Acharya, V.; Viswanathan, S. Leverage, Moral Hazard, and Liquidity. J. Financ. 2011, 66, 99-138. [CrossRef]

9. Barclay, M.; Smith, C.; Morellec, E. On the Debt Capacity of Growth Options. J. Bus. 2006, 79, 37-60. [CrossRef]

10. Qi, Y.; Roth, L.; Wald, J. Creditor Protection Laws, Debt Financing, and Corporate Investment over the Business Cycle. J. Int. Bus. Stud. 2017, 48, 477-497. [CrossRef]

11. Korteweg, A. The Net Benefits to Leverage. J. Financ. 2010, 65, 2137-2170. [CrossRef]

12. Henderson, B.; Jegadeesh, N.; Weisbach, M. World Markets for Raising New Capital. J. Financ. Econ. 2006, 82, 63-101. [CrossRef]

13. Lins, K.; Strickland, D.; Zenner, M. Do Non-U.S. Firms Issue Equity on U.S. Stock Exchanges to Relax Capital Constraints? J. Financ. Quant. Anal. 2005, 40, 109-133. [CrossRef]

14. Guo, C.; Sarkar, S.; Zhu, J.; Wang, Y. R\&D Investment, Business Performance, and Moderating Role of Guanxi: Evidence from China. Ind. Mark. Manag. 2020, 91, 55-63.

15. Bougheas, S. Internal vs. External Financing of R\&D. Small Bus. Econ. 2004, 22, 11-17.

16. Dawar, V. Agency Theory, Capital Structure and Firm Performance: Some Indian Evidence. Manag. Financ. 2014, 40, 1190-1206. [CrossRef]

17. Fama, E. Agency Problems and the Theory of the Firm. J. Polit. Econ. 1980, 88, 288-307. [CrossRef]

18. Bhagat, S.; Welch, I. Corporate Research and Development Investment: International Comparisons. J. Account. Econ. 1995, 19, 443-470. [CrossRef]

19. Czarnitzki, D.; Hottenrott, H. Financial Constraints: Routine versus Cutting Edge R\&D Investment. J. Econ. Manag. Strategy 2011, 20, 121-157.

20. Balakrishnan, S.; Fox, I. Asset Specificity, Firm Heterogeneity and Capital Structure. Strategy Manag. J. 1993, 14, 3-16. [CrossRef]

21. Williamson, O. Markets and Hierarchies; Free Press: New York, NY, USA, 1975.

22. Williamson, O. Corporate Finance and Corporate Governance. J. Financ. 1988, 43, 567-591. [CrossRef]

23. O'Brien, J. The Capital Structure Implications of Pursuing a Strategy of Innovation. Strategy Manag. J. 2003, 24, 415-431. [CrossRef]

24. Zantout, Z. A Test of the Debt-monitoring Hypothesis: The Case of Corporate R\&D Expenditures. Financ. Rev. 1997, 32, 21-48.

25. Jensen, M. Agency Costs of Free Cash Flow, Corporate Finance, and Takeovers. Am. Econ. Rev. 1986, 76, 323-329.

26. Cassell, C.; Huang, S.; Manuel, S.; Stuart, M. Seeking Safety: The Relation between CEO Inside Debt Holdings and the Riskiness of Firm Investment and Financial Policies. J. Financ. Econ. 2012, 103, 588-610. [CrossRef]

27. Dodd, O. Why Do Firms Cross-list Their Shares on Foreign Exchanges? A Review of Cross-listing Theories and Empirical Evidence. Rev. Behav. Financ. 2013, 5, 77-99. [CrossRef]

28. $\mathrm{Xu}, \mathrm{H}$.; Fu, Y.; Jasinskas, E. Can Cross-listing Improve Investment Efficiency? Empirical Evidence from China. Econ. Res.-Ekon. Istraz. 2020, 34, 1789-1813. 
29. Brandt, M.; Santa-Clara, P.; Valkanov, R. Parametric Portfolio Policies: Exploiting Characteristics in the Cross-section of Equity Returns. Rev. Financ. Stud. 2009, 22, 3411-3447. [CrossRef]

30. Chen, S.; Ho, K.; Ik, K. The Wealth Effect of New Product Introductions on Industry Rivals. J. Bus. 2005, 78, 969-996. [CrossRef]

31. Grullon, G.; Kanatas, G.; Kumar, P. The impact of capital structure on advertising competition: An empirical study. J. Bus. 2006, 79, 3101-3124. [CrossRef]

32. Kumar, P. The Impact of Long-term Client Relationships on the Performance of Business Service Firms. J. Serv. Res. 1999, 2, 4-18. [CrossRef]

33. Malshe, A.; Agarwal, M. From Finance to Marketing: The Impact of Financial Leverage on Customer Satisfaction. J. Mark. 2015, 79, 21-38. [CrossRef]

34. Maksimovic, V. Capital Structure in Repeated Oligopolies. Rand J. Econ. 1988, 19, 389-407. [CrossRef]

35. Roberts, M.; Samuelson, L. An Empirical Analysis of Dynamic, Nonprice Competition in an Oligopolistic Industry. Rand J. Econ. 1988, 19, 200-220. [CrossRef]

36. Satta, G.; Parola, F.; Penco, L.; Esposito De Falco, S. Insights to Technological Alliances and Financial Resources as Antecedents of High-tech Firms' Innovative Performance. RED Manag. 2016, 46, 127-144.

37. White, H. A Heteroscedasticity-consistent Covariance Matrix Estimator and a Direct Test for Heteroscedasticity. Econometrica 1980, 48, 817-838. [CrossRef]

38. Srinivasan, R.; Lilien, G.; Sridhar, S. Should Firms Spend More on Research and Development and Advertising during Recessions? J. Mark. 2011, 75, 49-65. [CrossRef]

39. Greene, W. Econometric Analysis, 8th ed.; Pearson: New York, NY, USA, 2018.

40. Bradley, M.; Jarrell, G.; Kim, E. On the Existence of an Optimal Capital Structure: Theory and Evidence. J. Financ. 1984, 39, 857-878. [CrossRef]

41. Sundaram, A.; John, T.; John, K. An Empirical Analysis of Strategic Competition and Firm Values: The Case of R\&D Competition. J. Financ. Econ. 1996, 40, 459-486.

42. Guo, M.; Yang, N.; Zhang, Y. Focal Enterprises' Control and Knowledge Transfer Risks in R\&D Networks: The Mediating Role of Relational Capability. Eur. J. Innov. Manag. 2020, 24, 870-892. 